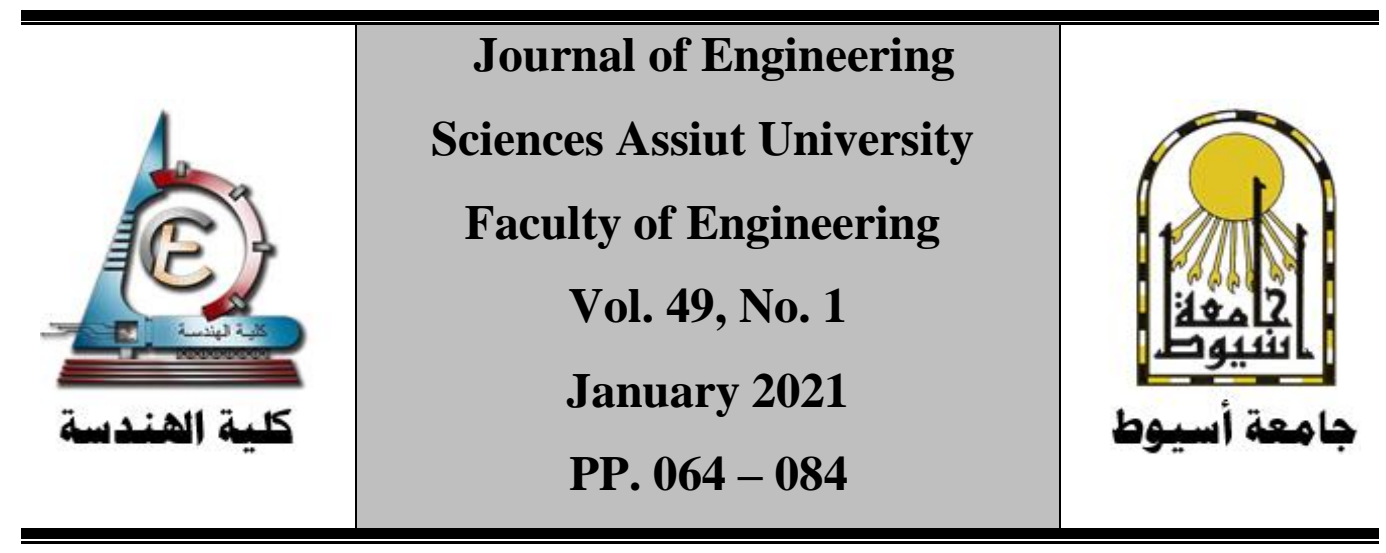

\title{
CONVEYANCE LOSSES ESTIMATION FOR OPEN CHANNELS IN MIDDLE EGYPT \\ CASE STUDY: ALMANNA MAIN CANAL, AND ITS DISTRIBUTARIES
}

\section{Tarek Sayed Abuzeid}

\author{
Civil Engineering Department, Assiut University, Assiut, Egypt \\ *tareksayed1986@aun.edu.eg
}

Received 10 January 2021; Revised 02 February 2021; Accepted 03 February 2021

\begin{abstract}
Whereas the irrigation water transmission open channel network in Egypt, is one of the largest and longest networks all over the world that dogged in permeable soil (about $33500 \mathrm{~km}$ in length). In a country that suffers greatly from an increasing shortage of limited available irrigation water quantities, ignoring the expected huge quantities of irrigation water losses through transport operations is a path of madness, to bridge the accelerated gap between what is required, and what is exist. Irrigation water conveyance losses include seepage, evaporation, and transpiration losses. Such losses are differentiated according to, type of soil, weather condition, and beneficiaries' traditions and behaviors. So, conducting field studies in various agricultural representative regions in Egypt, would be the most effective way for estimating the lost quantities of irrigation water all over the country through seepage, evaporation, and transportation basses. This way, decision-makers can use such acquired quantities for solving the problems of lack or non-arrival of irrigation water to the ends of some canals. In the present paper, the results of a field study carried out on one of the main irrigation canals in Assiut governorate in middle Egypt is introduced, as a case study represents the region of Middle Egypt area. The results of this field study in combination
\end{abstract}


with similar studies conducted in various agricultural regions across Egypt, can provide the decision-makers with the needed documented data, on the basis of which, water resources can be managed at the state level in the way, that maximizes the return from the available limited water, for irrigation and contributes to solve some irrigation problems of the large deficit between the available and required of irrigation water. Almanna canal belongs to Abnoub Irrigation Engineering Administration in Assiut, was chosen to conduct the present field study as a representative open channel having specific properties from different technical points of view, soil type, weather condition, and the length with its off-taking canals. The used data in this research were collected from the field and through the official Ministry of water resources and irrigation authority in Assiut governorate. Results indicate that, the total loss of irrigation water from Almanna canal and its branches (79.90 Km length) reaches about 16.05 million cubic meters per month, which represent $23.90 \%$ of the actual discharges that give to the Almanna canal and its branches. The lost water through only seepage reaches about 15.95 million cubic meters per month, representing $99 \%$ of all lost irrigation water. While, the rate of increase in the evaporation losses at earthen sections more than the designed sections losses can be neglected. Thus, the lining of Almanna canal and its branches is the most effective solution for saving such a huge amount of water, and directed it to irrigate some newly reclaimed areas, in addition, to solve the problems of non-arrival of the irrigation water to the ends of some irrigation canals. At the same time, improving the environmental situation of the surrounding agricultural community.

Keywords: Seepage losses; irrigation water transportation; Agricultural community's environment.

\section{Introduction}

Open canals are the common method used to convey water for irrigation in Egypt. Irrigation canals network in Egypt for all levels suffer from water deficit, distorted sections and un-equitable distribution of irrigation water among beneficiaries, however, little or no attention is given to the evaluation of conveyance systems. So, its modernization became omnipresent to overcome the problem of water shortage by the end of canals. The old land which is irrigated by surface irrigation is estimated as $79 \%$ of all cropped areas in Egypt. So, it is very important 
to improve the irrigation system in this area by increasing the irrigation transport efficiency [1].

A large portion of the water diverted into irrigation channels is lost in transit, this loss is composed of five parts: (a) leakage, (b) waste, (c) seepage, (d) evaporation, and (e) transpiration, by leakage is meant the water lost through poorly maintained gates and structures. Waste represents the amount which is lost through automatic waste ways or merely discharged into waste ways. Although the waste and leakage may be very high in some instances, these losses are out of the scope of this study. Three basic causes of such water losses will be discussed in this paper which are as: losses due to evaporation, losses due to seepage, and losses due to transpiration (through the weeds and the vegetation on the bank of channels).

\subsection{Seepage Loss}

Seepage loss is one of the major components of water loss from canals. The reduction or elimination of seepage losses in irrigation canals by means of linings assures better conveyance of the irrigation water and an improved economic situation. Seepage losses from earthen irrigation channels depend on a number of factors and vary from (30 to 50) percent of the discharge available at the head of an irrigation system [2]. Canal seepage primarily depends upon the soil permeability, water depth in the canal, length of wetted perimeter, channel geometry, location of groundwater table, velocity of the flowing water, shear stress (force of moving water on bed), slope between surface of water in canal and beneath groundwater surface of an aquifer, constrains on groundwater flow e.g. drains, rivers and streams $[\mathbf{3}, \mathbf{4 , 5}$, and 6]. Less significant are viscosity of canal water, canal water salinity, sediment load and distribution of size, canal age and plants [3 and 6].

Seepage is measured in the field, through the inflow- outflow, ponding, point measurement, and permeameter measurement method. Also, double ring infiltration test, ADCP (Acoustic Doppler Current Profiler) and electrical resistivity tests are also carried out for seepage estimation [7]. Seepage can be reduced up to 30 to $40 \%$ with lining but seepage cannot be controlled completely [6,8, and 9]. The presence of cracks in the lining greatly reduces its effectiveness [10]. Seepage can be reduced by reducing the wetted perimeter and increasing flow velocity [11]. Optimization models based on a genetic algorithm reduces water transportation losses in canals. This is carried out by providing a 
reasonable arrangement of canal water allocation times and discharges [12]. The seepage loss was studied at Ismailia canal sections in variable stages using empirical and analytical formulae and found the minimum seepage losses occurred at section which started from Km. (0.00) to Km. (10.05) and the maximum seepage losses occurred at section started from $\mathrm{Km}(49.00)$ to $\mathrm{Km}(67.00)$ [13]. Also, the results showed that the maximum expected seepage losses is $0.645 \mathrm{~m}^{3} / \mathrm{sec} / \mathrm{km}$, which represent about 20\% from the total discharge. Bakry and Awad [14] developed four equations to estimate the seepage in earthen canals using the InflowOutflow method. The equations are only valid for earthen canals having discharge ranging from 2 to $20 \mathrm{~m}^{3} / \mathrm{sec}$. Based on the results of the study given by Eshetu and Alamirew [15], the average values of seepage loss in the canals were $0.55 \%$ per $100 \mathrm{~m}$ and $0.84 \%$ per $100 \mathrm{~m}$ for lined and unlined primary canals respectively. Canal concrete liners normally decrease the seepage losses through the bottoms and sides; prevent weed growth and retard moss accumulation. They also decrease erosion from high velocities, reduce maintenance costs, and increase the capacity of the canal to convey water. However, they do not eliminate seepage loss [16].

\subsection{Evaporation Loss}

It is the transfer of the water from the liquid to vapor stage. As the canal water is exposed to the atmosphere at the surface, loss due to evaporation is obvious. The evaporation losses are very small as compared to the seepage losses. It is of course true that in most of the cases evaporation loss is not significant. It is may range from 0.25 to $1 \%$ of the total canal discharge [17]. Methods commonly used for estimating evaporation loss from canals are given by Liu et al. [18], and McJannet, et al. [19]: the evaporation pan, the water balance method, the heat balance method (also known as the energy balance method), and the aerodynamic method. Evaporation pans have been commonly used to observe open water evaporation such as a large area of open lake [19]. Generally, irrigation canals are very narrow and long, and the flow speed of water is relatively high. Thus, it is very difficult to implement the evaporation pans on a running water surface [20]. Substantial efforts have been performed to estimate the evaporation loss from agricultural irrigation canals. The evaporation from canals was estimated by using a simple empirical relationship between evaporation rate and water surface area [21], but for simplicity, the author assumed that the evaporation rate of 
canal water was equal to that of a local water surface without considering the complexity of natural environment conditions. The aerodynamic method based on the double-deck surface air layer model (DSAL) used for estimating evaporation loss from irrigation canals [22]. Results showed that cumulative evaporation instances estimated by the DSAL model were equal in order of magnitude to those by the heat balance method. Several former studies (e.g. Burt [23], and Chen and Jia [24]) have attempted to use the water balance method to estimate the evaporation loss from irrigation canals. It is well known that the rate of evaporation from open water depends on the surface wind speed and increases directly with it. The rate of evaporation from a running water surface depended not only on the surface wind speed but also on the flow speed of water [25], and they constructed a formula describing the functional dependence of evaporation rate on wind speed and water flow speed.

\subsection{Transpiration Loss}

Some amount of water flowing through the canals is lost by the process of transpiration. The plants, grass and weeds or other vegetation that grow on the banks of the canals undergo transpiration thereby resulting in loss water from the canal transpiration losses are very less in comparison to the seepage and evaporation losses in the canal. Aquatic vegetation distort canal design features (increase sedimentation, decrease channel flow, etc.), and reduce water quality. In general, designed capacity of irrigation canals has not accounted for flow resistance caused by aquatic vegetation [26]. Aquatic vegetation management in irrigation systems requires the use of a variety of techniques to maintain the water flow critical to agricultural productivity and profitability and to protect and preserve important natural resources [27].

Researches showed that in the near future Egypt will face scarcity of water [28]. So the amount of water available should be increased by finding new sources of water other than the Nile, i.e., desalination of seawater, rain harvesting, and reuse of wastewater. At the same time, preserving and decreasing the waste of water from existing water sources will combat the expected water scarcity in Egypt. For example, decreasing seepage, transpiration (through the weeds and the vegetation on the bank of channels), and evaporation that results from irrigation canals will preserve the quantity of surface water in these canals. This is 
goal of this study, to quantify the seepage, transpiration, and evaporation losses from Almanna canal and its irrigation canal network in Abnoub, Assuit, Egypt, so as to preserve this amount of water that otherwise would have been lost. The utility of the present research is of immense importance at the planning and design stage.

\section{Materials and Methods}

\subsection{Description of the study area}

Almanna canal was chosen to conduct the present field study as a representative open channel having specific properties from different technical points of view, soil type, weather condition, and the length with its off-taking canals. Almanna canal belongs to Abnoub Irrigation Engineering Administration in Assiut. It is located between $27^{\circ} 16^{\prime}$ and $27^{\circ} 33^{\prime}$ north latitude and between $31^{\circ} 27^{\prime}$ and $31^{\circ} 01^{\prime}$ east Longitude. The area is characterized by arid climate. The elevation of agricultural land is at $48 \mathrm{~m}$ above the mean sea water level. The length of the canal is about $32.80 \mathrm{~km}$ and its intake located at $\mathrm{km} 157$ at right bank for the Eastern Naga Hammady canal as shown in Fig. (1). Canal cropped area is 13500 feddan. 20 distributary canals are branched from Almanna canal on both sides as shown in Fig. (2). The total length of the branches is about $47.10 \mathrm{~km}$. Winter crops are wheat, clover, bean and summer crops are Y-corn, sorghum, and basil. The meteorological data of the region is shown in Table (1), [29]. Table (2) shows the dimensions, characteristics, and discharges of the different sections of Almanna canal. It was firstly constructed between Al-Matmar and Al-Maabda to carry fresh water for irrigation. It has 4 regulators constructed along the total length. The first is a head regulator at $\mathrm{km}(0.00)$, the second at $\mathrm{km}$. (10.45), the third at $\mathrm{km}$. (16.45), and the fourth at km. (23.06). The dimensions, characteristics, and discharges of Almanna off-taking canals were shown in the following table (3). Manning equation is used for calculating the earthen (actual) and the designed discharges of canals as given in the tables (2), and (3). Manning equation could be written as:

$$
Q=\frac{1}{n} \times S^{0.5} \times A \times R^{2 / 3}
$$


Where Q: water discharge $\left(\mathrm{m}^{3} / \mathrm{s}\right)$, S: friction slope it could be taken as water slope as demonstrated in Table (2) and Table (3) $(\mathrm{m} / \mathrm{km}), \mathrm{R}$ : hydraulic radius $(\mathrm{m})$, and $\mathrm{A}$ : area of hydraulic section $\left(\mathrm{m}^{2}\right)$.

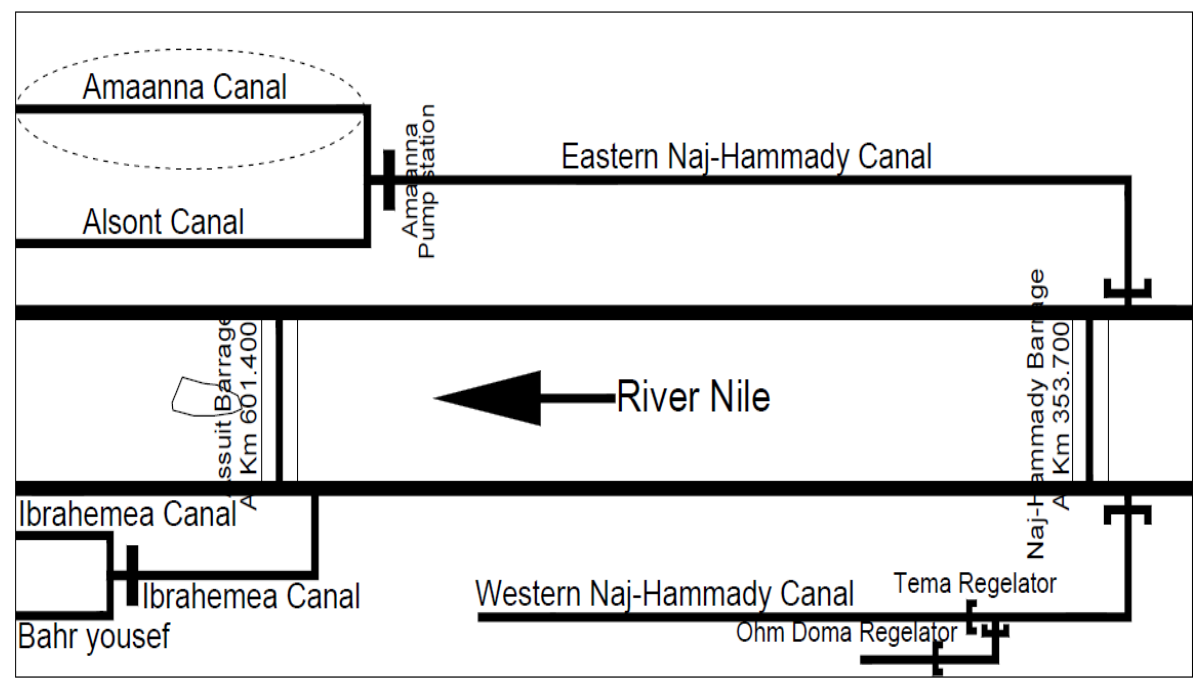

Fig. 1. Description of the study canal network

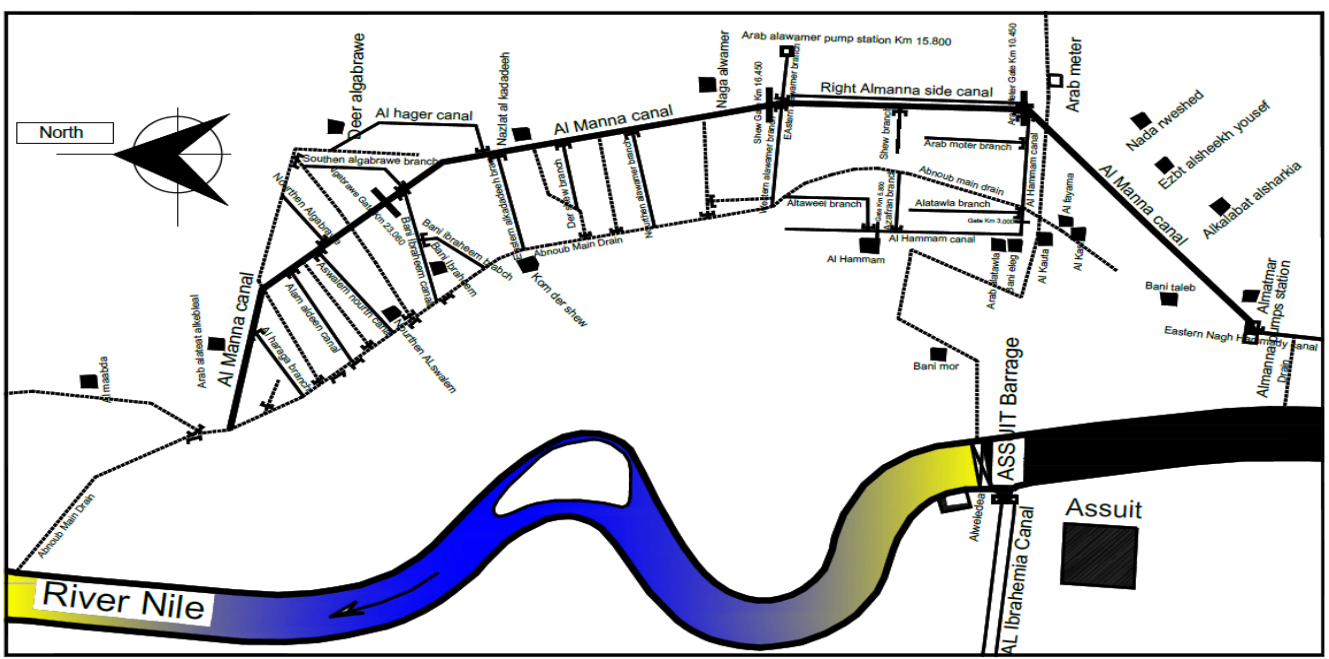

Fig. 2. Layout of Al-Manna canal and its distributaries 
Tarek S, Abuzeid, Conveyance Losses Estimation for Open Channels in Middle Egypt......

Table: 1. Meteorological data of Al-manna canal and its distributaries, [29]

\begin{tabular}{|c|c|c|c|c|c|c|c|}
\hline Month & $\begin{array}{l}\text { Max. Temp. } \\
{ }^{\circ} \mathrm{C}\end{array}$ & $\begin{array}{l}\text { Min. Temp. } \\
{ }^{\circ} \mathrm{C}\end{array}$ & $\begin{array}{l}\text { Avg. Temp. } \\
{ }^{\circ} \mathrm{C}\end{array}$ & $\begin{array}{c}\% \mathrm{RH} \\
\max \end{array}$ & $\begin{array}{c}\text { Pan Evaporation } \\
\mathrm{mm} / \text { day }\end{array}$ & $\begin{array}{l}\text { wind speed } \\
(\mathrm{km} / \mathrm{h})\end{array}$ & $\begin{array}{c}\text { No. of sunny } \\
\text { hours / day }\end{array}$ \\
\hline Jan & 18 & 6.50 & 22.40 & 60.30 & 2.80 & 16.00 & 8.90 \\
\hline Feb. & 22.5 & 11.20 & 26.10 & 52.60 & 3.20 & 17.30 & 9.70 \\
\hline Mar. & 25 & 14.20 & 30.50 & 42.90 & 4.40 & 19.80 & 9.90 \\
\hline Apr. & 29 & 17.10 & 35.10 & 36.50 & 6.40 & 21.30 & 10.30 \\
\hline May & 32 & 22.00 & 38.10 & 35.10 & 6.60 & 20.30 & 11.40 \\
\hline Jun. & 36 & 24.90 & 40.70 & 37.40 & 6.90 & 21.00 & 12.30 \\
\hline Jul. & 37 & 25.30 & 39.10 & 41.50 & 7.40 & 19.50 & 12.20 \\
\hline Aug. & 34.5 & 24.80 & 40.30 & 40.70 & 8.00 & 19.80 & 11.90 \\
\hline Sep. & 29 & 23.80 & 38.50 & 46.20 & 7.00 & 21.70 & 10.80 \\
\hline Oct. & 29 & 20.90 & 33.00 & 51.30 & 5.70 & 19.20 & 10.00 \\
\hline Nov. & 27 & 13.20 & 27.00 & 54.70 & 5.00 & 15.20 & 9.40 \\
\hline Dec. & 22.5 & 9.00 & 23.20 & 63.20 & 3.10 & 16.80 & 9.00 \\
\hline
\end{tabular}

Table: 2. Dimensions, characteristics, and discharges of the different sections of Almanna canal (Side Slope 3:2).

\begin{tabular}{|c|c|c|c|c|c|c|c|c|c|c|}
\hline No & Sections & Gate & $\begin{array}{c}\text { Area } \\
\text { (Fedd.) }\end{array}$ & $\begin{array}{c}\text { Length } \\
(\mathrm{Km})\end{array}$ & $\begin{array}{l}\text { Long. Slope } \\
(\mathrm{m} / \mathrm{Km})\end{array}$ & $\begin{array}{l}\text { Bed Width } \\
(\mathrm{m})\end{array}$ & $\begin{array}{c}\text { Bed } \\
\text { Level }\end{array}$ & $\begin{array}{l}\text { Water } \\
\text { level }\end{array}$ & $\begin{array}{l}\mathrm{Q}_{\text {Earthen }} \\
\left(\mathrm{m}^{3} / \mathrm{sec}\right)\end{array}$ & $\begin{array}{l}\mathrm{Q}_{\text {Designed }} \\
\left(\mathrm{m}^{3} / \mathrm{sec}\right)\end{array}$ \\
\hline 1 & $(0.00-10.45)$ & $\begin{array}{c}\text { Intake regulator-Arab } \\
\text { Meter }\end{array}$ & 0.000 & 10.450 & 0.00004 & 10.00 & 49.00 & 51.25 & 12.30 & 19.34 \\
\hline 2 & $(10.45-16.45)$ & Arab Meter-Shew & 7450 & 6.0000 & 0.00005 & 7.50 & 48.30 & 51.00 & 14.33 & 21.79 \\
\hline 3 & $(16.45-23.06)$ & Shew- Algabrawe & 3280 & 6.6100 & 0.00005 & 6.00 & 48.00 & 50.40 & 8.14 & 14.65 \\
\hline 4 & $(23.06-26.40)$ & Algabrawe - End & 2600 & 3.3400 & 0.00010 & 4.00 & 47.67 & 49.73 & 5.52 & 8.23 \\
\hline 5 & $(26.40-32.80)$ & End & 170.0 & 6.4000 & 0.00005 & 3.00 & 47.25 & 49.42 & 4.04 & 7.55 \\
\hline
\end{tabular}


Table: 3. Dimensions, characteristics, and discharges of Almanna branched or off-taking canals (Side Slope 1:1).

\begin{tabular}{|c|c|c|c|c|c|c|c|c|c|c|c|c|}
\hline No & Canal & Canal feed & $\mathrm{Km}$ & Bank & $\begin{array}{l}\text { Area } \\
\text { (Fedd.) }\end{array}$ & $\begin{array}{l}\text { Length } \\
(\mathrm{Km})\end{array}$ & $\begin{array}{l}\text { Long. } \\
\text { Slope } \\
(\mathrm{m} / \mathrm{Km})\end{array}$ & $\begin{array}{c}\text { Bed } \\
\text { Width }\end{array}$ & $\begin{array}{l}\text { Bed } \\
\text { level }\end{array}$ & $\begin{array}{l}\text { Water } \\
\text { level }\end{array}$ & $\begin{array}{c}Q_{\text {Earthen }} \\
\left(\mathrm{m}^{3} / \mathrm{sec}\right)\end{array}$ & $\begin{array}{l}\text { Q Designed } \\
\left(\mathrm{m}^{3} / \mathrm{sec}\right)\end{array}$ \\
\hline 1 & R. Almanna s. canal & Almanna & 10.50 & Right & 1000 & 5.827 & 0.00010 & 2.0 & 49.60 & 50.80 & 1.76 & 2.05 \\
\hline 2 & Al Hammam & Almanna & 10.50 & Left & 3400 & 9.000 & 0.00005 & 4.0 & 49.00 & 50.60 & 1.07 & 4.39 \\
\hline $2-1$ & Arab meter branch & Al Hammam & 1.000 & Left & 600 & 2.000 & 0.00005 & 2.0 & 49.30 & 50.50 & 0.34 & 1.45 \\
\hline $2-2$ & Al Atawla & Al Hammam & 3.000 & Left & 500 & 2.400 & 0.00010 & 1.5 & 49.20 & 50.40 & 0.81 & 1.65 \\
\hline $2-3$ & Al Zafran & Al Hammam & 6.30 & Left & 400 & 2.300 & 0.00005 & 1.5 & 49.00 & 50.29 & 0.18 & 1.34 \\
\hline $2-3$ & Al Taweel & Al Hammam & 6.940 & Left & 500 & 2.400 & 0.00010 & 1.5 & 48.50 & 50.10 & 0.64 & 2.92 \\
\hline 3 & Shew & Amanna & 12.50 & Right & 450 & 2.300 & 0.00010 & 1.0 & 49.00 & 50.20 & 0.20 & 1.26 \\
\hline 4 & Western Al Awamer & Almanna & 16.30 & Left & 200 & 0.800 & 0.00005 & 1.0 & 48.80 & 50.28 & 0.42 & 1.38 \\
\hline 5 & Eastern Alawamer & Almanna & 16.30 & Left & 400 & 0.670 & 0.00005 & 1.0 & 48.75 & 50.00 & 0.01 & 0.04 \\
\hline 6 & Northen Alawamer & Almanna & 17.80 & Left & 780 & 1.400 & 0.00005 & 1.5 & 49.00 & 50.55 & 0.29 & 1.93 \\
\hline 7 & Der Shew & Almanna & 19.80 & Left & 400 & 1.000 & 0.00005 & 1.0 & 48.55 & 49.45 & 0.05 & 0.50 \\
\hline 8 & Eastern Al kadadeeh & Almanna & 21.80 & Left & 400 & 1.000 & 0.00005 & 1.0 & 48.50 & 49.60 & 0.12 & 0.74 \\
\hline 9 & Al Hager & Almanna & 22.80 & Right & 500 & 4.200 & 0.00010 & 1.5 & 48.20 & 49.10 & 0.20 & 0.95 \\
\hline 10 & Bani Ibraheem & Almanna & 23.80 & Left & 800 & 1.400 & 0.00005 & 2.0 & 48.00 & 49.65 & 0.52 & 1.74 \\
\hline $10-1$ & Bani Ibraheem bran. & B. Ibraheem & 0.250 & Left & 400 & 1.350 & 0.00005 & 1.0 & 48.00 & 49.20 & 0.03 & 1.45 \\
\hline 11 & Southern Al Gabrawe & Almanna & 23.80 & Left & 500 & 2.200 & 0.00010 & 1.0 & 48.00 & 49.50 & 0.46 & 2.01 \\
\hline 12 & No.n Al Gabrawe & Almanna & 25.65 & Left & 400 & 1.350 & 0.00005 & 1.0 & 48.00 & 49.15 & 0.08 & 0.81 \\
\hline 13 & Alswalem & Almanna & 26.40 & Left & 700 & 1.800 & 0.00010 & 1.5 & 47.70 & 49.00 & 0.17 & 1.93 \\
\hline 14 & Alam Aldeen & Almanna & 27.60 & Left & 500 & 1.600 & 0.00005 & 1.0 & 47.49 & 48.70 & 0.10 & 0.90 \\
\hline 15 & Al Haraga & Almanna & 28.35 & Left & 500 & 2.100 & 0.00010 & 1.0 & 47.60 & 48.75 & 0.12 & 1.15 \\
\hline
\end{tabular}




\subsection{Determination of Seepage loss}

In this part, the empirical formula of Molesworth and Yennidunia was used for estimating the seepage losses in different earthen sections for all canals of Almanna network. This formula is used in Egypt to estimate seepage loss [30, 31], and is given as follows:

$$
\mathrm{S}=\mathrm{C} \times \mathrm{L} \times \mathrm{P} \times \mathrm{R}^{\wedge 0.50}
$$

Where $\mathrm{S}$ is the conveyance losses for a given canal length $\left(\mathrm{m}^{3} / \mathrm{sec}\right), \mathrm{L}$ is the canal length in $\mathrm{km}$., $\mathrm{P}$ is the wetted perimeter in $\mathrm{m}, \mathrm{R}$ is the hydraulic radius in $\mathrm{m}$, and $\mathrm{C}$ is the factor depends on soil types, for clay equal to 0.0015 .

For each canal, the maximum seepage losses in different earthen sections every $300 \mathrm{~m}$ were estimated by using the empirical formula of Molesworth and Yennidunia. The calculation of the seepage losses for the different earthen sections of Almanna canal and its branches were summarized as shown in the following Tables (5) and (6) respectively. From these tables, it is clear that the maximum value of Almanna canal seepage losses are in part one from intake regulator to $\mathrm{km} \mathrm{10.45.} \mathrm{Also,}$ the minimum value of the same losses are in part four from $\mathrm{km} 23.030$

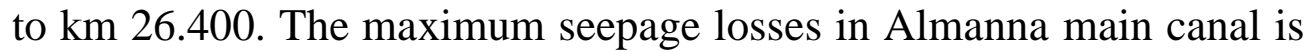
$0.601 \mathrm{~m}^{3} / \mathrm{sec} / \mathrm{km}$, which represent about $32.5 \%$ from the total discharge. For the branches of Almanna canals, the maximum and minimum seepage losses are in between $0.0571 \mathrm{~m}^{3} / \mathrm{sec} / \mathrm{km}$ in Al-Hammam canal and $0.0038 \mathrm{~m}^{3} / \mathrm{sec} / \mathrm{km}$ in Eastern Al-Kadadeeh canal.

\subsection{Determination of Evaporation loss}

In this study, evaporation pan method was used to observe the evaporation losses of Almanna canal and its branches by using the meteorological data shown in Table (1). The designed or earthen sections of canals subject to evaporation losses. So, the available meteorological data was used to estimate the rate of increase in the evaporation losses at earthen sections more than the designed sections. For estimating the evaporation losses for the different section of Almanna canal branches in all months of year, the width of water surface in the different sections of canals every 200 or $300 \mathrm{~m}$ was measured, the value of the pan evaporation for each month as shown in Table (1) was 
used. Then, the evaporation losses were calculated by using Eq. (3) [22] as follows:

$$
\mathrm{R}=(\mathrm{E} \times \mathrm{W} \times \mathrm{L}) \times \mathrm{Q}
$$

Where $E$ is the rate of evaporation $\left(\mathrm{m}^{3} /\right.$ day), $W$ the width of water surface in the canal $(\mathrm{m})$, and Q the discharge $\left(\mathrm{m}^{3} /\right.$ day). Since the rate of evaporation changes with time of day, $\mathrm{R}$ changes depending on the transportation spell and $\mathrm{L}$ length in $\mathrm{m}$.

According to the pan evaporating in the Arab Alawamer meteorological station [29], the minimum and maximum values of evaporation are in January, $2.82 \mathrm{~mm} /$ day and July, $8.00 \mathrm{~mm} /$ day respectively. Therefore, the seventh and eighth columns of Tables (5) and (6) show the summarized values of the maximum and minimum evaporation losses for the different earthen sections of Almanna canal and its branches respectively. From these tables it is clear that the maximum rate of increase in evaporation losses in earthen sections more than the designed sections are in part one, which started from intake regulator to $\mathrm{km} 10.45$. While, the minimum rate of increase in evaporation losses are in part four, which started from $\mathrm{km} 23.03$ to $\mathrm{km}$ 26.40. In Table (6), at Almanna branched canals, the negative values of evaporation losses rate clarify that the designed sections subject to evaporation losses more than the earthen sections because the width of the actual earthen sections are less than the width of designed sections as shown in Fig. (3).

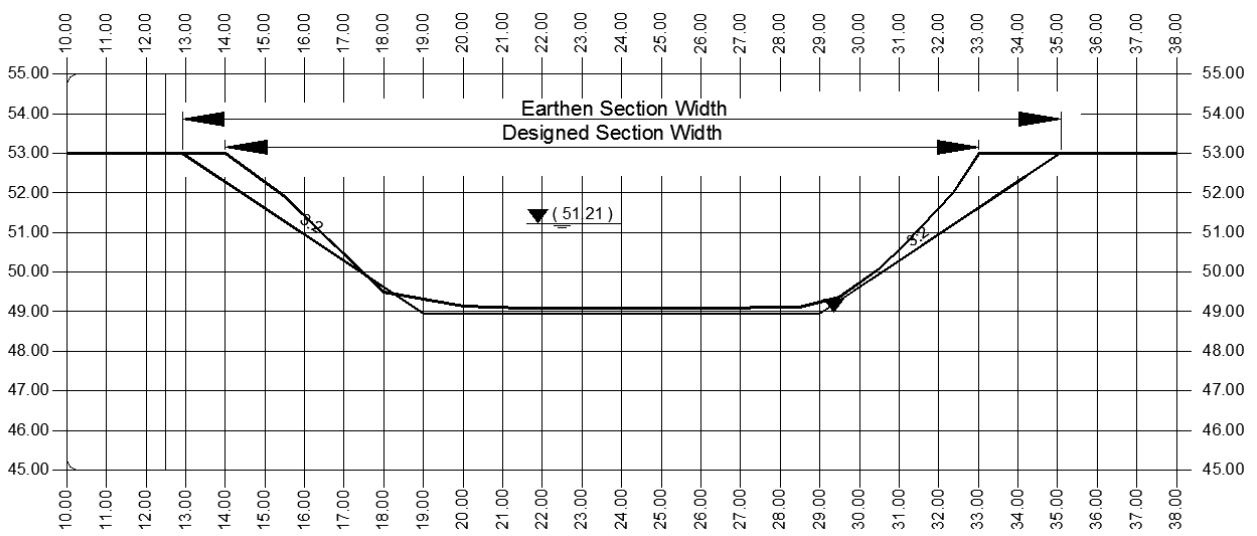

Fig. 3. Negative rate of evaporation losses. 


\subsection{Determination of Transpiration losses}

In the present field study, the transpiration losses for grass and weeds are computed using an approach introduced by El-Enany et al. [31] as follows:

$$
W C=\left(\frac{E T_{O} K_{a} A}{1000}\right) \times \frac{4200}{86400}
$$

Where $W C$ is the water consumption needed for the area served by a distributary canal during a month $\left(\mathrm{m}^{3} / \mathrm{sec}\right.$.), ETo is the monthly average evapotranspiration for the area served by a distributary canal ( $\mathrm{mm} /$ day), $K a$ is monthly average crop coefficient, and $A$ is the cultivated area (feddan).

The reference evapotranspiration ETo was estimated by using CROPWATER Software for weeds and grass that located inside slopes and bed of canals using available meteorological data at Arab ALawamer local weather station as shown in Table (1), [29]. Measuring wheel, Fig. (4), is used for measuring slope lengths, banks widths and distance of grass and weeds at canals network. Fig. (5) shows the reference evapotranspiration for weeds using CROPWATER software. Jensen et al. [32] compared 20 methods of computing ETo for arid and humid locations. They found that the Penman-Monteith method was the most accurate for either environment. Because of its accuracy, the Penman-Monteith method is recommended when air temperature, relative humidity, wind speed, and solar radiation data are available [32].

The average crop coefficient $\left(\mathrm{K}_{\mathrm{a}}\right)$ must include the basal crop coefficient $\left(\mathrm{K}_{\mathrm{Cb}}\right)$ and the effect of wet soil evaporation $\left(\mathrm{K}_{\mathrm{w}}\right)$. If water stress is expected, an appropriate stress factor $\left(\mathrm{K}_{\mathrm{s}}\right)$ can also be selected although this is generally not done [33, and 34]. The average crop coefficient $\left(\mathrm{K}_{\mathrm{a}}\right)$ is defined as:

$$
K_{a}=\left(K_{c b} \times K_{s}\right)+K_{w}
$$

Where $\mathrm{K}_{\mathrm{cb}}=$ basal crop coefficients [34]; $\mathrm{K}_{\mathrm{S}}=$ stress factor to reduce water use for stressed crops (water stress factor) equal to 1 [30]; and $\mathrm{K}_{\mathrm{w}}$ $=$ factor to account for increase evaporation (wet soil evaporation factor) [34, and 35]. 


$$
K_{w}=F_{w} \times\left(1-K_{c b}\right) \times A_{f}
$$

Where $F_{w}=$ the fraction of the soil surface wetted that take 1.0 for basin irrigation, and $A_{f}=$ the average wet soil evaporation factor, [19] as shown in Table (4).

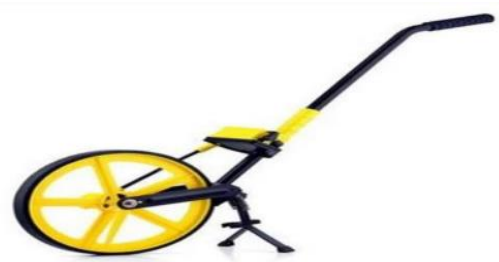

Fig. 4. Measuring Wheel.

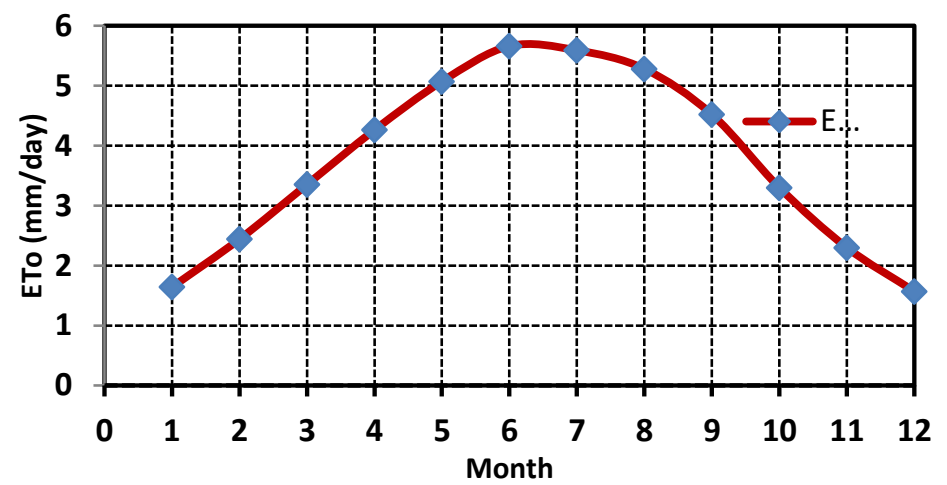

Fig. 5. Reference evapotranspiration (ETo) $\mathrm{mm} /$ day

Table: 4. Values of coefficient $\mathrm{K}_{\mathrm{cb}}, \mathrm{K}_{\mathrm{s}}, \mathrm{K}_{\mathrm{w}}$, and $\mathrm{K}_{\mathrm{a}}$ for evapotranspiration.

\begin{tabular}{|c|c|c|c|c|c|c|}
\hline Crop & $\mathrm{K}_{\mathrm{cb}}$ & $\mathrm{K}_{\mathrm{s}}$ & $\mathrm{F}_{\mathrm{w}}$ & $\mathrm{A}_{\mathrm{f}}$ & $\mathrm{K}_{\mathrm{w}}$ & $\mathrm{K}_{\mathrm{a}}$ \\
\hline \multirow{4}{*}{$\tilde{\widetilde{J}}$} & 0.25 & 1 & 1 & 0.511 & 0.38 & 0.63 \\
\cline { 2 - 7 } & 0.63 & 1 & 1 & 0.511 & 0.19 & 0.82 \\
\cline { 2 - 7 } & 1.20 & 1 & 1 & 0.511 & 0.00 & 1.20 \\
\cline { 2 - 7 } & 1.20 & 1 & 1 & 0.511 & 0.00 & 1.20 \\
\cline { 2 - 7 } & 1.20 & 1 & 1 & 0.511 & 0.00 & 1.20 \\
\cline { 2 - 7 } & 0.86 & 1 & 1 & 0.511 & 0.07 & 0.93 \\
\cline { 2 - 7 } & 1.00 & 1 & 1 & 0.511 & 0.00 & 1.00 \\
\hline
\end{tabular}

The water is lost during on-days. The last three columns of tables (5) and (6) show the area of grass and weeds as measured from Almanna canal and its distributaries by the measuring wheel, the minimum and maximum evapotranspiration losses resulting due to these weeds and grass respectively. From these tables it is clear that minimum and 
maximum of transpiration losses are in January and July respectively. At Almanna canal, the maximum rate of transpiration losses are in part one from intake regulator to $\mathrm{km} 10.450$ and minimum rate of transpiration losses are in part four from $\mathrm{km} 23.030$ to end at $\mathrm{km} 26.400$. It may be due to the length of the section, as the section length increase, the amount of weeds and grass increases and therefore the transpiration losses increases. At Almanna branched canals, the maximum and minimum transpiration losses due to grass and weeds area in canals are shown in the following Table (6). Figure (6) shows the weeds and grass on the banks and sides of a canal in the study area.

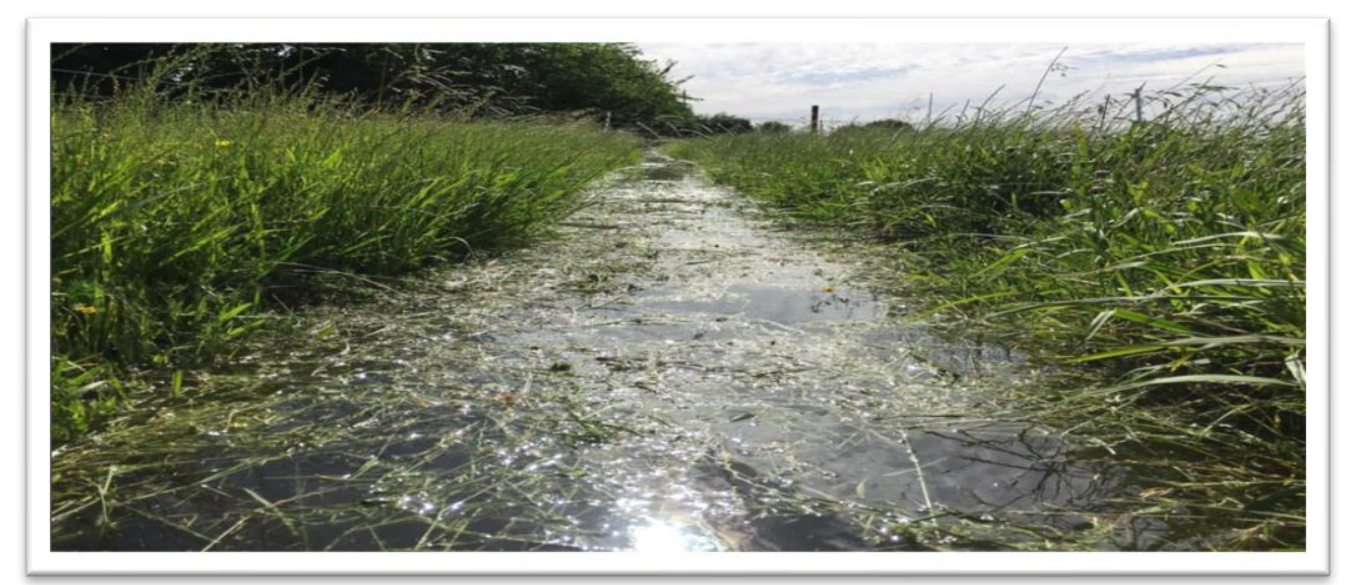

Fig. 6. Grass and weeds in Almanna canal

\section{Results and Discussion}

The following Tables (7) and (8) show the maximum values of the total losses in Almanna canal and its branches. From these tables it is clear that:

- The seepage losses are the major losses, while the losses due to evaporation is the lowest in Almanna canal.

- The seepage losses represented more than $99 \%$ of the total conveyances' losses, which estimated at about 14.36, 1.59 million $\mathrm{m}^{3}$ per month, which representing $25.18 \%, 16.47 \%$ of the actual discharge in Almanna Canal and its branches, respectively.

- The maximum percentage of the total losses occurred in the first part (Km 0.000 to 10.450) of Almanna canal and its equals $32.55 \%$ of the 
designed discharge. While the minimum percentage of the total losses occurred in the fourth part (Km 23.030 to 26.400) of Almanna canal equals $4.05 \%$ of the designed discharge, this may be due to the length of part, discharge, wetted perimeter, type of soil, and the density of grass and weeds.

- The maximum and minimum amount of total water lost through the whole length of Almanna canal equals $14425185.19 \mathrm{~m}^{3} / \mathrm{month}$ and $14385145.54 \mathrm{~m}^{3} /$ month, respectively.

- In branches of Almanna canal, the seepage losses are the major losses, while the rate of increase in the evaporation losses at earthen sections more than the designed sections losses can be neglected.

- In branches of Almanna canal, the maximum percentage of the total water losses occurred in the Right Almanna side canal and AlHammam canal and its equals $15.56 \%, 11.79 \%$ of the designed discharge, respectively. While the minimum percentage of the total water losses occurred in the Eastern Al kadadeeh canal and DerShew canal and its equals $0.52 \%, 0.54 \%$ of the designed discharge, respectively.

- The maximum and minimum amount of total water lost through all branches of Almanna canal equals $1620316.748 \mathrm{~m}^{3} /$ month and $1600332.604 \mathrm{~m}^{3} /$ month, respectively.

Thus, the lining of Almanna canal and its branches is the most effective solution for saving such a huge amount of water, and directed it to irrigate some newly reclaimed areas, in addition, to solve the problems of non-arrival of the irrigation water to the ends of some irrigation canals. At the same time, the velocity of water in the canal will increase as the surface of the canal will be smooth due to the rugosity coefficient is improved, maintenance cost of the canal can be significantly decreased, and improving the environmental situation of the surrounding agricultural community. 
Tarek S, Abuzeid, Conveyance Losses Estimation for Open Channels in Middle Egypt......

Table: 5. Maximum seepage losses of Almanna canal actual earthen section:

\begin{tabular}{|c|c|c|c|c|c|c|c|c|c|c|}
\hline No & $\mathrm{Km}$ & $\begin{array}{l}\text { Designed } \\
\text { Discharge }\end{array}$ & $\begin{array}{c}\text { Actual } \\
\text { Discharge }\end{array}$ & $\begin{array}{c}\text { Seepage loss } \\
\left(\mathrm{m}^{3} / \mathrm{s} / \mathrm{km}\right)\end{array}$ & $\begin{array}{l}\text { Total Seepage } \\
\text { loss }\left(\mathrm{m}^{3} / \text { day }\right)\end{array}$ & $\begin{array}{l}\text { Min Rate of } \\
\text { Ev. }\left(\mathrm{m}^{3} / \text { day }\right)\end{array}$ & $\begin{array}{l}\text { Max Rate of } \\
\text { Ev. }\left(\mathrm{m}^{3} / \text { day }\right)\end{array}$ & $\begin{array}{c}\text { Weed area } \\
\text { feddan }\end{array}$ & $\begin{array}{l}\text { Min WC } \\
\left(\mathrm{m}^{3} / \text { day }\right)\end{array}$ & $\begin{array}{l}\text { Max WC } \\
\left(\mathrm{m}^{3} / \text { day }\right)\end{array}$ \\
\hline 1 & $0.000-10.45$ & 1671141.88 & 1062567.62 & 0.6010 & 542630.15 & 111.00 & 317.15 & 37.17 & 316.92 & 1047.2465 \\
\hline 2 & $10.45-16.45$ & 1882671.00 & 1238339.63 & 0.3066 & 158962.11 & 41.77 & 119.33 & 20.91 & 178.27 & 589.0762 \\
\hline 3 & $16.45-23.06$ & 1265351.41 & 702872.66 & 0.2423 & 138376.86 & 28.79 & 82.25 & 24.39 & 207.98 & 654.5291 \\
\hline 4 & $23.03-26.40$ & 710868.17 & 465260.57 & 0.0984 & 28403.40 & 15.10 & 43.15 & 11.62 & 99.04 & 327.2645 \\
\hline 5 & $26.40-32.80$ & 652265.34 & 349443.78 & 0.1617 & 89438.34 & 11.78 & 33.65 & 22.07 & 188.17 & 654.4837 \\
\hline
\end{tabular}

Table: 6. Maximum seepage losses from actual earthen section of Almanna branched canals

\begin{tabular}{|c|c|c|c|c|c|c|c|c|c|c|}
\hline No & Canal & $\begin{array}{l}\text { Designed } \\
\text { Discharge }\end{array}$ & $\begin{array}{c}\text { Actual } \\
\text { Discharge }\end{array}$ & $\begin{array}{c}\text { Seepage loss } \\
\left(\mathrm{m}^{3} / \mathrm{s} / \mathrm{km}\right)\end{array}$ & $\begin{array}{l}\text { Total Seepage } \\
\text { loss }\left(\mathrm{m}^{3} / \text { day }\right)\end{array}$ & $\begin{array}{l}\text { Min Rate of } \\
\text { Ev. }\left(\mathrm{m}^{3} / \text { day }\right)\end{array}$ & $\begin{array}{l}\text { Max Rate of } \\
\text { Ev. }\left(\mathrm{m}^{3} / \text { day }\right)\end{array}$ & $\begin{array}{l}\text { Weed area } \\
\text { feddan }\end{array}$ & $\begin{array}{l}\text { Min WC } \\
\left(\mathrm{m}^{3} / \text { day }\right)\end{array}$ & $\begin{array}{l}\text { Max WC } \\
\left(\mathrm{m}^{3} / \text { day }\right)\end{array}$ \\
\hline 1 & R.Almanna s. canal & 177025.28 & 151996.79 & 0.0542 & 27291.472 & 17.84 & 50.61 & 6.91 & 58.92 & 194.68 \\
\hline 2 & Al Hammam & 379180.67 & 92168.27 & 0.0571 & 44399.822 & 04.34 & 12.31 & 10.21 & 87.05 & 287.65 \\
\hline $2-1$ & Arab meter branch & 125175.78 & 29300.99 & 0.0068 & 1176.7828 & -05.48 & -01.93 & 3.8 & 32.40 & 107.06 \\
\hline $2-2$ & Al Atawla & 142271.26 & 70081.83 & 0.0217 & 4499.6003 & 10.37 & 29.41 & 4.90 & 41.78 & 138.05 \\
\hline $2-3$ & Al Zafran & 115899.52 & 15450.98 & 0.0154 & 3056.9558 & 01.78 & 05.05 & 6.66 & 56.78 & 187.64 \\
\hline $2-3$ & Al Taweel & 252027.76 & 54959.34 & 0.0231 & 4789.9882 & 04.14 & 11.74 & 2.48 & 21.14 & 69.87 \\
\hline 3 & Shew & 108628.41 & 17404.20 & 0.0085 & 1681.2518 & -08.71 & -03.07 & 3.22 & 27.45 & 90.72 \\
\hline 4 & Western Al Awamer & 119179.92 & 36535.36 & 0.0062 & 659.7653 & 02.37 & 06.72 & 0.92 & 07.85 & 25.92 \\
\hline 5 & Eastern Alawamer & 3737.94 & 1258.82 & 0.0047 & 269.3273 & 02.03 & 05.33 & 0.66 & 05.63 & 18.60 \\
\hline 6 & Northen Alawamer & 167118.47 & 25299.38 & 0.0104 & 1261.1675 & 00.70 & 01.98 & 1.09 & 09.29 & 30.71 \\
\hline 7 & Der Shew & 42942.39 & 4377.73 & 0.0507 & 221.6157 & -00.59 & -00.21 & 1.26 & 10.74 & 16.90 \\
\hline 8 & Eastern Al kadadeeh & 64260.14 & 10049.24 & 0.0038 & 325.6952 & -00.53 & -00.20 & 1.31 & 11.17 & 36.91 \\
\hline 9 & Al Hager & 109951.36 & 17704.63 & 0.0174 & 6298.4147 & -00.73 & -02.06 & 4.70 & 40.07 & 91.62 \\
\hline 10 & Bani Ibraheem & 150435.59 & 45160.80 & 0.0132 & 1596.7906 & 05.14 & 14.59 & 0.65 & 05.54 & 18.31 \\
\hline $10-1$ & Bani Ibraheem branch & 125175.78 & 2555.36 & 0.0084 & 983.0117 & 02.69 & 07.64 & 2.12 & 18.08 & 59.73 \\
\hline 11 & Southern Al Gabrawe & 173429.19 & 39705.32 & 0.0158 & 3008.8308 & 04.45 & 12.61 & 1.77 & 15.09 & 49.87 \\
\hline 12 & Nor. Al Gabrawe & 70373.05 & 7314.13 & 0.0051 & 593.7150 & -02.02 & -00.71 & 2.03 & 17.31 & 57.19 \\
\hline 13 & Alswalem & 166417.12 & 15031.11 & 0.0095 & 1484.4719 & -04.38 & -01.55 & 1.82 & 15.52 & 51.28 \\
\hline 14 & Alam Aldeen & 78139.31 & 8948.50 & 0.0064 & 885.1465 & -08.58 & -03.02 & 2.09 & 17.82 & 58.88 \\
\hline 15 & Al Haraga & 99522.53 & 10192.58 & 0.0089 & 1615.3509 & 00.48 & 01.37 & 4.01 & 34.19 & 112.98 \\
\hline
\end{tabular}


Table: 7. Maximum conveyance losses from Almanna canal.

\begin{tabular}{|c|c|c|c|c|c|c|c|c|}
\hline \multirow{2}{*}{$\mathrm{N}$} & \multirow{2}{*}{$\mathrm{Km}$} & \multirow{2}{*}{$\begin{array}{c}\text { Designed } \\
\text { Discharge }\left(\mathrm{m}^{3} / \text { day }\right) \\
\end{array}$} & \multirow{2}{*}{$\begin{array}{c}\text { Actual Discharge } \\
\left(\mathrm{m}^{3} / \text { day }\right)\end{array}$} & \multicolumn{3}{|c|}{ Losses $\left(\mathrm{m}^{3} /\right.$ day $)$} & \multirow{2}{*}{$\begin{array}{c}\text { Total } \\
\text { Losses }\end{array}$} & \multirow{2}{*}{$\begin{array}{c}\% \text { of Total } \\
\text { Losses }\end{array}$} \\
\hline & & & & Evaporation & Transpiration & Seepage & & \\
\hline 1 & $0.0000-10.450$ & 1671141.88 & 1062567.62 & 317.15 & 1047.246 & 542630.15 & 543994.5 & 32.55 \\
\hline 2 & $10.450-16.450$ & 1882671.00 & 1238339.63 & 119.33 & 589.0762 & 158962.11 & 159670.5 & 8.48 \\
\hline 3 & $16.45-23.060$ & 1265351.41 & 702872.66 & 82.25 & 654.5291 & 138376.86 & 139113.6 & 10.99 \\
\hline 4 & $23.030-26.400$ & 710868.17 & 465260.57 & 43.15 & 327.2645 & 28403.40 & 28773.82 & 4.05 \\
\hline 5 & $26.400-32.800$ & 652265.34 & 349443.78 & 33.65 & 654.4837 & 89438.34 & 90126.48 & 13.82 \\
\hline
\end{tabular}

Table: 8.Maximum conveyance losses from Almanna branched canals.

\begin{tabular}{|c|c|c|c|c|c|c|c|c|}
\hline \multirow{2}{*}{$\mathrm{N}$} & \multirow{2}{*}{$\mathrm{Km}$} & \multirow{2}{*}{$\begin{array}{c}\text { Designed } \\
\text { Discharge }\left(\mathrm{m}^{3} / \text { day }\right)\end{array}$} & \multirow{2}{*}{$\begin{array}{l}\text { Actual Discharge } \\
\left(\mathrm{m}^{3} / \text { day }\right)\end{array}$} & \multicolumn{3}{|c|}{$\operatorname{Losses}\left(\mathrm{m}^{3} /\right.$ day $)$} & \multirow{2}{*}{$\begin{array}{c}\text { Total } \\
\text { Losses) }\end{array}$} & \multirow{2}{*}{$\begin{array}{c}\% \text { of Total } \\
\text { Losses }\end{array}$} \\
\hline & & & & Evaporation & Transpiration & Seepage & & \\
\hline 1 & R.Almanna side. c & 177025.28 & 151996.79 & 50.61 & 194.6796 & 27291.472 & 27536.76 & 15.56 \\
\hline 2 & Al Hammam & 379180.67 & 92168.27 & 12.31 & 287.6525 & 44399.822 & 44699.79 & 11.79 \\
\hline 3 & Arab meter .b & 125175.78 & 29300.99 & -01.93 & 107.0597 & 1176.7828 & 1283.84 & 1.03 \\
\hline 4 & Al Atawla & 142271.26 & 70081.83 & 29.41 & 138.0506 & 4499.6003 & 4667.06 & 3.28 \\
\hline 5 & Al Zafran & 115899.52 & 15450.98 & 05.05 & 187.6362 & 3056.9558 & 3249.64 & 2.80 \\
\hline 6 & Al Taweel & 252027.76 & 54959.34 & 11.74 & 69.8705 & 4789.9882 & 4871.59 & 1.93 \\
\hline 7 & Shew & 108628.41 & 17404.20 & -03.07 & 90.7190 & 1681.2518 & 1771.97 & 1.63 \\
\hline 8 & W. Al Awamer & 119179.92 & 36535.36 & 06.72 & 25.9197 & 659.7653 & 692.40 & 0.58 \\
\hline 9 & E.Alawamer & 3737.94 & 1258.82 & 05.33 & 18.5946 & 269.3273 & 293.68 & 7.86 \\
\hline 10 & N.Alawamer & 167118.47 & 25299.38 & 01.98 & 30.7092 & 1261.1675 & 1293.85 & 0.77 \\
\hline 11 & Der Shew & 42942.39 & 4377.73 & -00.21 & 35.4987 & 221.6157 & 257.11 & 0.60 \\
\hline 12 & E. Al kadadeeh & 64260.14 & 10049.24 & -00.20 & 36.9074 & 325.6952 & 362.60 & 0.56 \\
\hline 13 & Al Hager & 109951.36 & 17704.63 & -02.06 & 132.4159 & 6298.4147 & 6430.83 & 5.85 \\
\hline 14 & Bani Ibraheem & 150435.59 & 45160.80 & 14.59 & 18.3128 & 1596.7906 & 1622.74 & 1.08 \\
\hline 15 & Bani Ibraheem bra. & 125175.78 & 2555.36 & 07.64 & 59.7280 & 983.0117 & 1057.33 & 0.84 \\
\hline 16 & S. Al Gabrawe & 173429.19 & 39705.32 & 12.61 & 49.8673 & 3008.8308 & 3071.31 & 1.77 \\
\hline 17 & N. Al Gabrawe & 70373.05 & 7314.13 & -00.71 & 57.1924 & 593.7150 & 650.91 & 0.92 \\
\hline 18 & Alswalem & 166417.12 & 15031.11 & -01.55 & 51.2760 & 1484.4719 & 1535.75 & 0.92 \\
\hline 19 & Alam Aldeen & 78139.31 & 8948.50 & -03.02 & 58.8828 & 885.1465 & 944.03 & 1.21 \\
\hline 20 & Al Haraga & 99522.53 & 10192.58 & 01.37 & 112.9761 & 1615.3509 & 1728.33 & 1.74 \\
\hline
\end{tabular}




\section{Conclusions}

Conveyances losses of Almanna canal and its branches were estimated by empirical formulas at different sections along the total length of the canals. The main conclusions can be summarized as follows:

(1) The total loss of irrigation water from Almanna canal and its branches reaches about 16.05 million cubic meters per month, which represent $12.08 \%$ of the designed discharges, while it represents $23.90 \%$ of the actual discharges that give to the Almanna canal and its branches.

(2) The lost water through only seepage reaches about 15.95 million cubic meters per month, representing $99 \%$ of all lost irrigation water.

(3) The lost water through the weeds and grass in Almanna canal, is estimated to be about $3272.6 \mathrm{~m}^{3} /$ day, while in the branches of Almanna canal estimated at about $1763.95 \mathrm{~m}^{3} /$ day.

(4) The rate of increase in the evaporation losses at actual earthen sections which is more than the designed sections losses, might be neglected in Almanna canal and its branches.

(5) According to the high values of conveyances losses in Almanna canal and its distributers, the need for linings has become very urgent to preserve these large quantities of water.

\section{References}

[1] Sabry. M., (2019). "Hydraulic Performance Assessment for Improved Irrigation System". M.SC. Thesis, university of Assuit, Egypt.

[2] Abu Gulul, K. A. J., (2004). "Lining of Irrigation Channels". M.Sc. Thesis, College of Engineering, Southampton University, India, 1975.

[3] Alam, M. and Bhutta, M., (2004). "Comparative Evaluation of Canal Seepage Investigation Techniques". Agricultural Water Management, 66(1), 65-76.

[4] International Commission on Irrigation and Drainage (ICID), (1968). "Controlling Seepage Losses from Irrigation Canals". Worldwide survey, New Delhi, India.

[5] Martin, C.A. and Gates, T.K., (2014). "Uncertainty of Canal Seepage Losses Estimated Using Flowing Water Balance with Acoustic Doppler Devices". Journal of Hydrology, 517, 746-761.

[6] Swamee, P.K., Mishra, G.C. and Chahar, B.R., (2000). "Design of Minimum Seepage Loss Canal Sections". Journal of Irrigation and Drainage Engineering, 126(1), 28-32.

[7] Zhang, Q., Chai, J., Xu, Z. and Qin, Y., (2016). "Investigation of Irrigation Canal Seepage Losses through Use of Four Different Methods in Hetao Irrigation District”. China. Journal of Hydrologic Engineering, 22(3), 05016035.

[8] Sepaskhah, A. and Salemi, H. (2004). "An Empirical Model for Prediction of 
Conveyance Efficiency for Small Earth Canals”. Iranian Journal of Sciences and Technology, 28, 623-628.

[9] Wachyan, E. and Rushton, K., (1987). "Water Losses from Irrigation Canals". Journal of Hydrology, 92(3-4), 275-288.

[10] Plusquellec, H., (2019). "Overestimation of Benefits of Canal Irrigation Projects: Decline of Performance over Time Caused By Deterioration of Concrete Canal Lining". Irrigation and Drainage. 68(3), 383 388.https://doi.org/10.1002/ird.2341.

[11] Soothar, R., Mirjat, M., Mangrio, M., Chandio, A. and Leghari, N., (2015). "Estimating Seepage Losses in Different Size of Earthen Watercourses at Farm Level'. Pakistan Journal of Agriculture, Agricultural Engineering and Veterinary Sciences, 31(1), 81-92.

[12] Yao, W., Ma, X. and Chen, Y., (2019). "Optimization of Canal Water in an Irrigation Network Based on A Genetic Algorithm: A Case Study of The North China Plain Canal System”. Irrigation and Drainage 68(2), 629-636.

[13] Mowafy, H.M., (2001). "Seepage Losses in Ismailia Canal”. Sixth International Water Technology Conference, IWTC, Alexandria, Egypt, pp.195-211.

[14] Bakry, M.F and Awad, A.A., (1997). "Practical Estimation of Seepage Losses along Earthen Canals in Egypt". Water Resources Management Vol.11, pp.197206.

[15] Eshetu, B.D. and Alamirew, T., (2018). "Estimation of Seepage Loss in Irrigation Canals of Tendaho Sugar Estate, Ethiopia". Eshetu and Alamirew, Irrigation Drainage Sys Engineering 7:3, Vol.7, No.3, pp.2-5.

[16] Up Irrigation Research Institute, (1984). "Report on Estimation of Seepage Losses from Canals by Radio Isotopes". UPIRI, Reo. TM 54, RR (G15), Roorkee, India.

[17] Sahasrabudhe, S.R., Katariya, s.k., and Sons, (2011). "Irrigation Engineering and Hydraulic Structures". Publisher of Engineering \& Compute Books, 3rd edition.

[18] Liu, S.; Wang, W.; Mori, M.; Kobayashi, T., (2016). "Estimating the Evaporation from Irrigation Canals in Northwestern China Using the DoubleDeck Surface Air Layer Model". Advanced Meteorology, 1-9.

[19] McJannet, D., Webster, I., Stenson, M., Sherman, B., (2008). "Estimating Open Water Evaporation for the Murray-Darling Basin". CSIRO: Collingwood, Australia, p. 58.

[20] Wang, W., Liu, S., Kobayashi, T., Kitano, M., (2013). "Evaporation from Irrigation Canals in the Middle Reaches of the Heihe River in the Northwest of China-A Preliminary Study”. J. Fac. Agric. Kyushu Univ., 58, 371-376.

[21] Wang, Y., (1987). "Calculation of the Evaporation from the Flowing Channels". Groundwater 1, 28-30.

[22] Suhua L., Weizhen W., Makito I., Tetsuo K., (2016). "Estimating the Evaporation from Irrigation Canals in Northwestern China Using the DoubleDeck Surface Air Layer Model", Advances in Meteorology, Article ID 3670257, 9 pages, https://doi.org/10.1155/2016/3670257.

[23] Burt, C.M., (1999). "Irrigation Water Balance Fundamentals" In Conference on Benchmarking Irrigation System Performance Using Water Measurement and Water Balances; Irrigation Training and Research Center: San Luis Obispo, CA, 
Tarek S, Abuzeid, Conveyance Losses Estimation for Open Channels in Middle Egypt......

USA, pp. 1-13.

[24] Chen, J., and Jia, Z., (2007) "Construction and Application of Water Balance Model In the Irrigation Districts of the Midstream Areas of the Heihe River Basin". In The Study of Humanities and Environment in the City of Blackwater City: International Symposium on Human Culture and Environment in the Blackwater City; Shen, W., Shi, J., Eds.; China Renmin University Press: Beijing, China, pp. 150-164.

[25] Kobayashi, T.; Liu, S.; Wang, W., (2013). "Modeling of the Evaporation from A Running Water Surface”. Kyushu J. Agric. Meteorol. Ser, 2, 1-14.

[26] Pitlo, R.H. and Dawson, F.H. (1993). "Flow-Resistance of Aquatic Weeds. In: Aquatic Weeds". A.H. Pieterse and K.J. Murphy (Eds.). Oxford Science Pub. pp. 74-84.

[27] Sytsma M. and Parker M., (1999). "Aquatic Vegetation in Irrigation Canals". Center for Lakes and Reservoirs Publications and Presentations. Paper 11. http://pdxscholar.library.pdx.edu/centerforlakes_pub/11

[28] Stanley J.D., and Clemente P.L., (2017). "Increased land subsidence and sealevel rise are submerging Egypt's Nile Delta Coastal Margin”. Geol Soc Am 27(5):4-11. https://doi.org/10.1130/gsatg312a.1

[29] Abdelazeez, M.H., (2.015). "Inter Relationship between Modern Irrigation System and Fertilizers Application Methods". ph. D thesis, Assiut university.

[30] Dolatkhah, S., Kazemiazar, F., Deljou, P. and Nourmand, B., (2015). "Simulation of Seepage from Earthen Canals of Moghan Irrigation and Drainage Network Using Seep/w Model". Bulletin of Environment, Pharmacology and Life Sciences, Bull. Env. Pharmacol. Life Sci. Journals. Vol.4 (1), pp.430-435. URL: http: //www.bepls.com.

[31] El-Enany, M. A., El-Alfy, K. S., Sobeih, M. F., Armanious, S. D., and Gergis, E. S., (2004). "Modification of the Improved Irrigation System in the Old Lands in Egypt". Vol.29, No.1.

[32] Jensen, M.E., Burman, R.D. and Allen, R.G. (1990). "Evapotranspiration and Irrigation Water Requirements". Amer. Soc. Civil Eng. Man. and Rep. on Eng. Prac. No. 70, New York, NY.

[33] Hanks, R.J., (1974). "Model for Predicting Plant Yield as Influenced by Water Use". Agronomy Journal, Vol.66, pp.660-665.

[34] Paul K. K., Gylan L. D., and Nelton O. S., (1993). "Part 623 National Engineering Handbook", Chapter 2, "Irrigation Water Requirements" Book, United States Department of Agriculture. Soil Conservation Service.

[35] Allen, G.R., Pereira, L. S., Raes, D. and Smith, M., (1998). "Crop Evapotranspiration, Guidelines for Computing Crop Water Requirements" FAO. Irrigation and drainages paper No 56. Rome, Italy. 


\section{تقدير فواقد النقل في القتوات المفتوحة في مصر الوسطى حالة در اسة: نرعة المعنا الرئيسية وفرو فئها.}

تعثبر شبكة قنوات الري المكثوفة في مصر من أكبر وأطول الثبكات في العالم التي

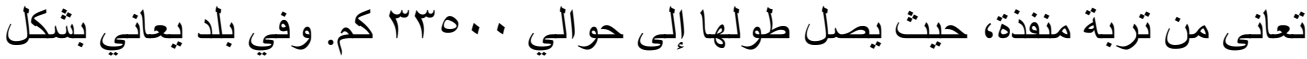

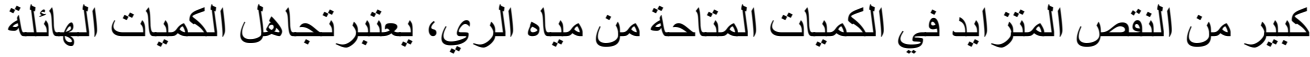

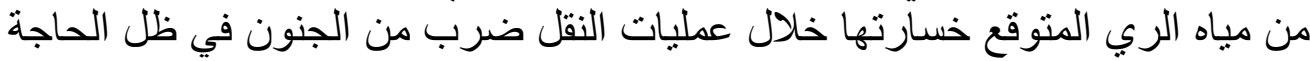

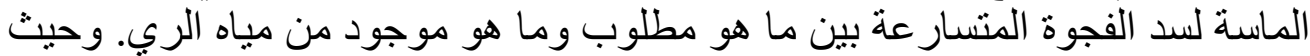

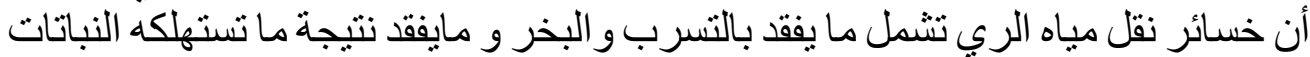

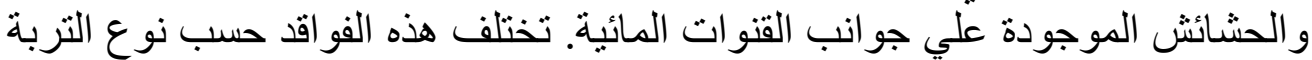

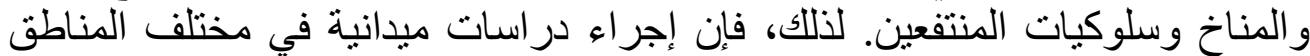

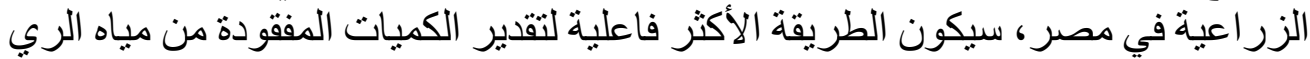

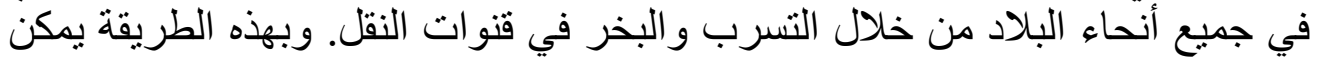

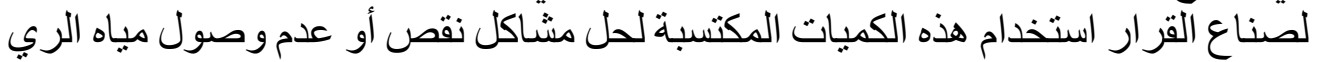

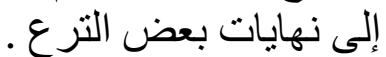
في هذه الورقة البحثية، تم تقديم نتائج در اسة ميدانية أجريت على إحدى قنوات

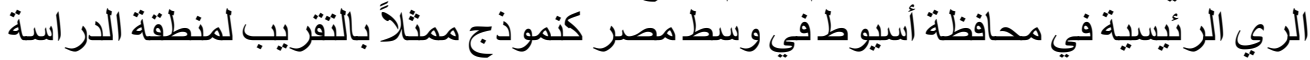

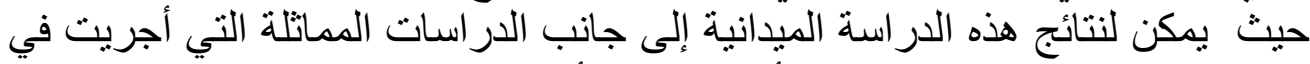

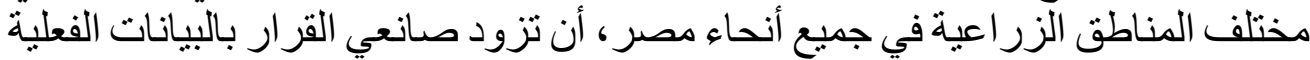

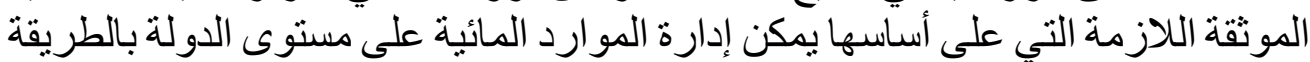

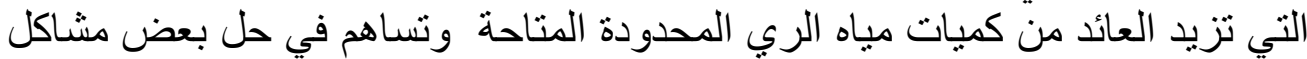

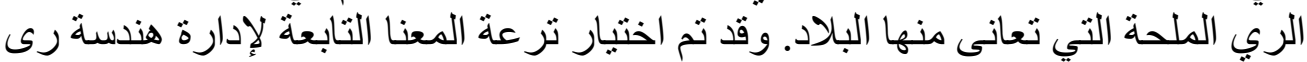

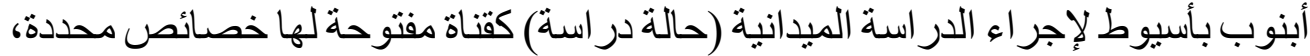

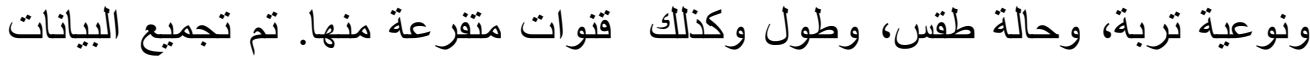

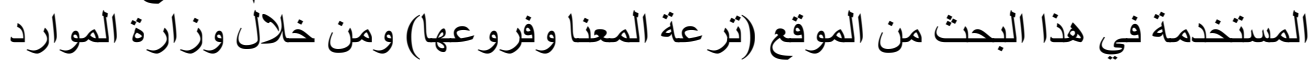

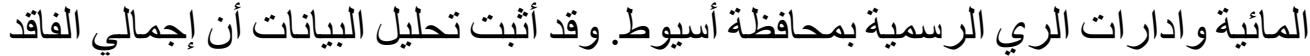

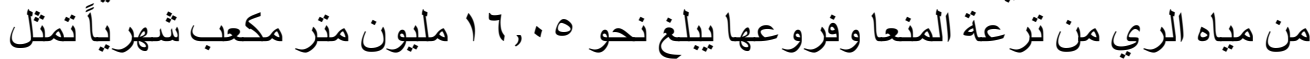

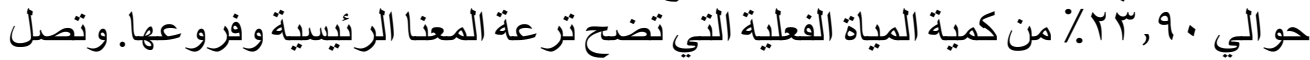

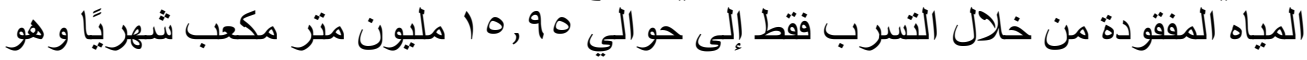

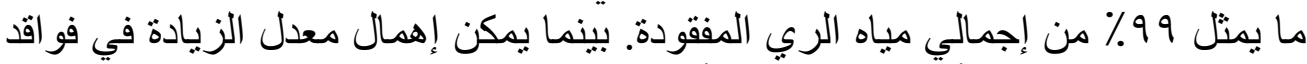

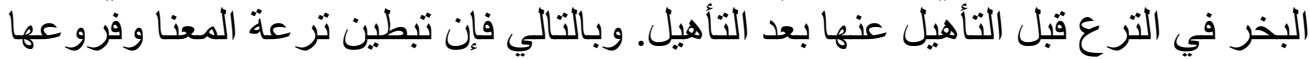

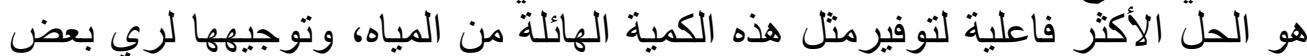

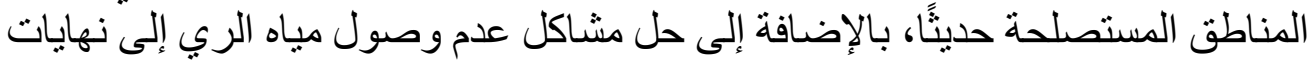
بعض قنوات الري. في نفس الوقت، تحسين الوضع البيئي للمجتمع الزر اعي المحيط. 